\title{
DNA methylation patterns in bladder cancer and washing cell sediments: a perspective for tumor recurrence detection Priscilla D Negraes ${ }^{1,2}$, Francine P Favaro1, João Lauro V Camargo ${ }^{2}$, Maria Luiza CS Oliveira² ${ }^{2}$ José Goldberg 3 , Cláudia A Rainho*1 and Daisy MF Salvadori²
}

Address: ${ }^{1}$ Department of Genetics, Biosciences Institute, UNESP, Sao Paulo State University, Botucatu, Sao Paulo, Brazil, ${ }^{2}$ Department of Pathology, Botucatu Medical School, UNESP, Sao Paulo State University, Botucatu, Sao Paulo, Brazil and ${ }^{3}$ Department of Urology, Botucatu Medical School, UNESP, Sao Paulo State University, Botucatu, Sao Paulo, Brazil. CEP 18618-000

Email: Priscilla D Negraes - prinegraes@yahoo.com.br; Francine P Favaro - franfavaro@yahoo.com.br; João Lauro

V Camargo - decam@fmb.unesp.br; Maria Luiza CS Oliveira - mdeolive@fmb.unesp.br; José Goldberg - goldberg@fmb.unesp.br;

Cláudia A Rainho* - rainho@ibb.unesp.br; Daisy MF Salvadori - dfavero@fmb.unesp.br

* Corresponding author

Published: 14 August 2008

BMC Cancer 2008, 8:238 doi:10.1 186/147/-2407-8-238

This article is available from: http://www.biomedcentral.com//47/-2407/8/238

(c) 2008 Negraes et al; licensee BioMed Central Ltd.

This is an Open Access article distributed under the terms of the Creative Commons Attribution License (http://creativecommons.org/licenses/by/2.0), which permits unrestricted use, distribution, and reproduction in any medium, provided the original work is properly cited.

\begin{abstract}
Background: Epigenetic alterations are a hallmark of human cancer. In this study, we aimed to investigate whether aberrant DNA methylation of cancer-associated genes is related to urinary bladder cancer recurrence.

Methods: A set of 4 genes, including CDHI (E-cadherin), SFN (stratifin), RARB (retinoic acid receptor, beta) and RASSFIA (Ras association (RalGDS/AF-6) domain family I), had their methylation patterns evaluated by MSP (Methylation-Specific Polymerase Chain Reaction) analysis in 49 fresh urinary bladder carcinoma tissues (including 14 cases paired with adjacent normal bladder epithelium, 3 squamous cell carcinomas and 2 adenocarcinomas) and 24 cell sediment samples from bladder washings of patients classified as cancer-free by cytological analysis (control group). A third set of samples included 39 archived tumor fragments and 23 matched washouts from 20 urinary bladder cancer patients in post-surgical monitoring. After genomic DNA isolation and sodium bisulfite modification, methylation patterns were determined and correlated with standard clinic-histopathological parameters.
\end{abstract}

Results: $C D H I$ and SFN genes were methylated at high frequencies in bladder cancer as well as in paired normal adjacent tissue and exfoliated cells from cancer-free patients. Although no statistically significant differences were found between RARB and RASSFIA methylation and the clinical and histopathological parameters in bladder cancer, a sensitivity of $95 \%$ and a specificity of $71 \%$ were observed for RARB methylation (Fisher's Exact test $(\mathrm{p}<0.000 \mathrm{I}$; $O R=48.89)$ and, $58 \%$ and $17 \%(P<0.05 ; O R=0.29)$ for RASSFIA gene, respectively, in relation to the control group.

Conclusion: Indistinct DNA hypermethylation of CDHI and SFN genes between tumoral and normal urinary bladder samples suggests that these epigenetic features are not suitable biomarkers for urinary bladder cancer. However, RARB and RASSFIA gene methylation appears to be an initial event in urinary bladder carcinogenesis and should be considered as defining a panel of differentially methylated genes in this neoplasia in order to maximize the diagnostic coverage of epigenetic markers, especially in studies aiming at early recurrence detection. 


\section{Background}

Urinary bladder cancer is the fourth most common malignancy in the Western world, with a male:female ratio of nearly four to one and a median age at diagnosis between 65 and 70 years [1]. Histologically, $90 \%$ to $95 \%$ of malignant bladder tumors are urothelial carcinoma (UC), formerly designated transitional cell carcinoma (TCC) [2]. Although more than $70 \%$ of the lesions are detected as non-invasive papillary carcinomas, which commonly recur, a poor prognosis is related to tumors that are already invasive at diagnosis ( 20\%) [3]. After transurethral resection of superficial bladder cancer, periodic cystoscopic monitoring is performed for early recurrence detection, with some cases requiring intravesical prophylactic instillation chemotherapy. Muscle invasive disease calls for more aggressive treatment, often consisting of radical cystectomy and bladder substitution [4].

At present, conventional diagnosis for urinary bladder cancer is based on morphological, histological and pathological features. These criteria provide essential prognostic information, but show insufficient power to precisely predict patient outcome. The need for accurate predictive markers has led to the search for molecular markers in bladder cancer patients [5]. The use of genetic and epigenetic alterations for the early detection of bladder cancer is promising because it is believed that some molecular events occur at the beginning of the carcinogenesis process. Thus, molecular diagnosis may allow detection before clinical or radiographic manifestations. In this context, a sensitive and specific noninvasive test could prescreen patients with clinical symptoms as well as those at high risk, and would also be useful in monitoring patients post-surgically for early detection of recurrence.

DNA-, RNA-based or/and immunohistochemical methods have been applied to identify new tumor markers or to estimate risk of tumor progression in UC. Several DNA alterations have been described in bladder cancer, such as allele losses or deletions [6], gene amplifications [7], DNA mutations [8] and microsatellite instabilities [9]. Furthermore, aberrant DNA methylation patterns have been recognized as common epigenetic changes in human cancer and are already detected in early cancer stages [10]. DNA methylation occurs on cytosine residues located at the 5' position of guanines in CpG dinucleotides [11]. Its distribution on the mammalian genome is not random and is especially important in CpG-rich areas, also called CpG islands. The promoter region of actively transcribing genes is frequently rich in this dinucleotide sequence, almost always unmethylated [12].

Dense DNA methylation in CpG islands of growth-regulating gene promoter regions is now recognized as a common alternative mechanism for gene inactivation in human cancer, an event as important as somatic mutations in coding regions of tumor suppressor genes (TSG) [13]. Usually both genetic and epigenetic events represent complementary hits involved in TSG inactivation [14]. A large number of studies have shown that loci of epigenetically inactivated TSG generally coincide with overlapping regions of allelic losses in human cancer, including UC [6,15-19]. In fact, loss of heterozygosity (LOH) assays have been widely used as indirect approaches in the search for a new TSG $[20,21]$. In the last few years, genetic studies have indicated that allelic loss in many distinct chromosomal regions, including $1 \mathrm{p}, 3 \mathrm{p}$, and $16 \mathrm{q}$, are associated with UC tumorigenesis [17-19,21]. It is important to notice that RASSF1A (Ras association (RalGDS/AF6) domain family 1 ) and $R A R B$ (retinoic acid receptor, beta) mapped at 3p (3p21.3 and 3p24, respectively), SFN (stratifin, also known as $14-3-3 \sigma$ ) located at 1 p35.3, and CDH1 (cadherin 1, type 1, E-cadherin [epithelial]) at 16q22.1, are epigenetically silenced TSGs located at loci that overlap with LOH minimal regions in human cancer.

RASSF1A protein probably modulates some of the growth inhibitory responses mediated by Ras, although its interaction with activated Ras remains unclear. This gene is considered a bona fide tumor suppressor epigenetically inactivated during human carcinogenesis, whose hypermethylation has also been reported in UC [22-30]. The $R A R B$ gene is a member of the thyroid-steroid hormone receptor superfamily of nuclear transcriptional regulators that binds retinoic acid (the biologically active form of vitamin A), and also mediates cellular signaling during embryonic morphogenesis, cell growth, and differentiation [31]. Retinoic acids exhibit tumor-suppressor activity due to their antiproliferative and apoptosis-inducing effects [32]. RARB has also presented high methylation frequencies in urinary bladder tumors (varying from 15\% to $93 \%)[15,22,24,25,30]$.

Initially, it was suggested that loss of stratifin expression could contribute to malignant transformation by disabling the cell cycle arrest at the G2 checkpoint, allowing the accumulation of genetic defects [33]. Subsequently, the down-regulation of SFN gene in various human cancers was generally attributed to the hypermethylation of its CpG island. To the best of our knowledge, there is only one previous study addressing SFN hypermethylation in UC where the highest frequency was found for squamous cell carcinomas irrespective of their grade of cellular malignancy $(80 \%)$. Furthermore, the authors found hypermethylation of $57.1 \%$ for high grade, high stage nonpapillary TCC; $28.6 \%$ for low grade, low stage papillary TCC; and $28 \%$ for undifferentiated small cell carcinomas, the lowest rate [34]. 
The CDH1 gene encodes for a calcium-dependent cell-cell adhesion glycoprotein, whose loss of function may contribute to cancer progression by increasing proliferation, invasion, or metastasis [35]. These findings suggest that CDH1 is a tumor- and invasion-suppressor gene [36]. Its relation to urinary bladder carcinogenesis was demonstrated through the observation of altered expression due to epigenetic changes in many studies, ranging from $9.5 \%$ hypermethylation [29] up to $87 \%$ in TCCs [37]. However, some studies have also evaluated TCCs, both in squamous cells and in situ carcinoma, and have shown a variable spectrum of hypermethylation for the same gene $[15,22,24,25,27,30,38-40]$.

In an effort to identify a possible association among epigenetic changes, urinary bladder cancer prognosis and early-recurrence, we analyzed the methylation pattern of CDH1, RARB, SFN and RASSF1A genes in 54 fresh samples of urinary bladder cancer, 14 of which were paired with tumor-adjacent normal urothelium; 39 paraffinembedded UC primary tumor and/or recurrence matched with 23 bladder washing sediments obtained from 20 patients under post-surgical monitoring. In addition, we analyzed a hospital-based control group consisting of 24 bladder washings from patients that reported urological complaints, but without any bladder tumor history and showing negative cytology for tumor cell presence.

\section{Methods}

\section{Sample collection and DNA extraction}

Methylation patterns of RASSF1A, RARB, SFN, and CDH1 genes were determined in two cell lineages, 5637 and T24, derived from non-invasive and invasive high-grade $\mathrm{UC}$, respectively. Fresh samples of tumoral urinary bladder tissues were obtained from 54 patients (44 males and 10 females; median age of 67.85 years, ranging from 40 to 90 years) who underwent surgical treatment at Amaral Carvalho Hospital, Jaú, SP, Brazil. Patients were recruited consecutively on the basis of tissue availability. Treatment for each patient consisted of initial endoscopic tumor resection and subsequent radical cystectomy for those with muscle invasive disease. Non-muscle invasive tumors underwent intravesical bacillus Calmette-Guerin (BCG) therapy. Normal adjacent tissue samples were also collected from each case. A tumor fragment and the matched normal adjacent tissue were fixed in formalin and embedded in paraffin. The corresponding hematoxylin-eosin-stained sections were evaluated by the same pathologist (JLVC) to determine tumor type, grade and growth pattern. Samples were trimmed to maximize the quantity of target tissue and only fragments with more than 70\% neoplastic cells were used for DNA extraction. After this evaluation, only 14 normal adjacent tissue samples exhibited an epithelial layer. Tumors were staged according to the 1998 WHO-ISUP classification [41].
A control group included 24 urinary bladder washings from patients that reported urological complaints, but without any bladder tumor history and showing negative cytology for tumor cell presence in the same bladder washing cell samples.

In addition, 20 patients in post-surgical monitoring, who underwent cytology analysis to detect tumor recurrence, were recruited at the Department of Urology from Botucatu Medical School, UNESP - Sao Paulo State University, Brazil. From this group was collected a total of 23 urinary bladder washings matched with 39 UC samples obtained from the Department of Pathology archive. Among these 20 patients 9 presented recurrent tumors (analysis until seven biopsies had been collected at distinct times) and 11 were primary tumors.

Genomic DNA from fresh bladder tissues, paraffinembedded samples and washout cell sediments were obtained by standard sodium dodecyl sulfate/proteinase $\mathrm{K}$ digestion, followed by phenol/chloroform extraction and ethanol precipitation.

All samples were collected after patients or their relatives had provided informed consent. Approval for research on human subjects was obtained from the respective ethic committees of both institutions and by the National Research Ethics Committee (CONEP 9382) Brasilia, DF, Brazil.

\section{Bisulfite treatment and Methylation-Specific Polymerase Chain Reaction (MSP)}

The conversion of DNA by sodium bisulfite was performed using an established protocol [42] with modifications. Initially, genomic DNA was denatured with $3 \mathrm{M}$ $\mathrm{NaOH}$ at $40^{\circ} \mathrm{C}$ for $15 \mathrm{~min}$ (final concentration of $0.3 \mathrm{M}$ $\mathrm{NaOH})$. The urea/bisulfite and hydroquinone solution (freshly prepared, $\mathrm{pH}$ 5.0) were then added to the denatured DNA to yield final concentrations of $5.36 \mathrm{M}, 3.44$ $\mathrm{M}$, and $0.5 \mathrm{mM}$, respectively, followed by 20 cycles of incubation at $55^{\circ} \mathrm{C}$ for $15 \mathrm{~min}$ followed by denaturation at $95^{\circ} \mathrm{C}$ for $30 \mathrm{sec}$ in a PTC200 Peltier Termal Cycler (MJ Research, Madison, USA). DNA was purified with the Wizard DNA Clean-UP System (Promega. Madison, WI, USA), and DNA modification was completed by the addition of $5.0 \mu \mathrm{l}$ of $\mathrm{NaOH} 3 \mathrm{M}$ at room temperature for 15 min. Precipitation was carried out through the addition of $30 \mu \mathrm{l}$ of ammonium acetate $5 \mathrm{M}$ (pH 7.0), $350 \mu \mathrm{l}$ of ethanol and $1 \mu \mathrm{l}$ of glycogen $(20 \mu \mathrm{g} / \mathrm{uL})$ (Invitrogen Life Technologies, Carlsbad, CA, USA). The bisulfite-modified DNA was resuspended in $20 \mu \mathrm{l}$ of sterile water and stored at $-20^{\circ} \mathrm{C}$

The methylation pattern of promoter regions for $C D H 1$, $R A R B, S F N$ and RASSF1A genes was evaluated by a MSP 
approach. For each gene, previously described primers specific to the methylated and unmethylated sequences were used [33,43-45]. DNA from lymphocytes of healthy volunteers treated with SssI methyltransferase (New England Biolabs, Beverly, MA, USA) and then subjected to bisulfite modification was used as positive controls for methylated alleles. The reaction was performed in a total volume of $50 \mu \mathrm{l}$ containing $10 \mu \mathrm{g}$ of genomic DNA, $10 \mathrm{U}$ of SssI methylase, $160 \mathrm{mM}$ of S-adenosyl-metionina, 50 $\mathrm{mM}$ of $\mathrm{NaCl}, 10 \mathrm{mM}$ of Tris- $\mathrm{HCl}, 10 \mathrm{mM}$ of $\mathrm{MgCl}_{2}, 1 \mathrm{mM}$ of DTT pH 7.9, during 18 hours at $37^{\circ} \mathrm{C}$.

Table 1 summarizes the oligonucleotide sequences, annealing temperature and product size for MSP analysis. To determine the methylation pattern within the $\mathrm{CpG}$ island in 5'UTR of the CDH1 gene, a nested-PCR approach was used as previously described in detail [46].

One-step MSP was performed to detect the methylation pattern of RARB, SFN and RASSF1A genes, using specific primers for the methylated and unmethylated sequences in distinct reactions, accomplished in a total volume of 25 $\mu \mathrm{l}$ containing $0.25 \mu \mathrm{M}$ of each primer, $200 \mu \mathrm{M}$ of each dNTP, 15 mM Tris-HCl, pH 8.0, 50 mM KCl, 1 U of AmpliTaq Gold (Applied Biosystems, Foster City, CA, USA) and $3 \mathrm{mM} \mathrm{MgCl}_{2}$ for $R A R B$ and $R A S S F 1 A$, and $2.5 \mathrm{mM} \mathrm{MgCl}_{2}$ for SFN.
The amplified products were visualized after electrophoresis in $6 \%$ polyacrylamide gel and silver nitrate staining [47]. Water blanks were included in each assay.

\section{Statistical analysis}

Descriptive mean and percentage statistics were used to summarize patient data and gene hypermethylation status. The presence of methylation and characteristics including age, sex and clinico-histopathological parameters were evaluated using Odds Ratio (OR) with Confidence Interval (CI) of 95\%. Pairwise associations followed dichotomous variables defined according to growth pattern (non-papillary versus papillary), differentiation grade (low versus high), tumor invasiveness (noninvasive versus invasive) [41], and presence or absence of tumoral recurrence. Potential associations on the presence of promoter methylation for each gene as well as the sensitivity and specificity of the assay for tumor recurrence were assessed using Fisher's Exact test with a 5\% significance level. Correlations between cytology and hypermethylation of bladder washings were considered to assess the relative hazar of recurrence. All statistical evaluations were performed using a computer-assisted program (SPSS - Statistical Package for The Social Sciences v15.0, SPSS Inc.).

Table I: Oligonucleotide sequences, annealing temperatures, and product size for MSP analysis.

\begin{tabular}{|c|c|c|c|c|c|}
\hline Gene (MS) & Primers 5'- 3' & Position of interrogated CpGs* & $\mathrm{Ta}\left({ }^{\circ} \mathrm{C}\right)$ & Product size (bp) & Ref. \\
\hline \multicolumn{6}{|l|}{ CDHI } \\
\hline \multirow[t]{2}{*}{ Methylated allele } & $\begin{array}{l}\text { GTAGTTACGTATTTATTTTTAAGTGGCGT } \\
\text { C (F) }\end{array}$ & $-14 ; 4 ; 7$ & 53 & 112 & [43] \\
\hline & CGAATACGT CGAATCGAACCG (R) & $68 ; 73 ; 78 ; 82 ; 88$ & & & \\
\hline Unmethylated allele & $\begin{array}{l}\text { TGGTTGTAGTTATGTATTTATTTTTAAGTG } \\
\text { GTGTT (F) } \\
\text { ACACCAATACAACAAATCAAACCAAA } \\
\text { (R) }\end{array}$ & & 53 & 120 & \\
\hline \multicolumn{6}{|c|}{ N } \\
\hline \multirow[t]{2}{*}{ Methylated allele } & GAACGCGAGCGATTCGAGT (F) & III; II3; II7; I22 & 55 & 158 & [44] \\
\hline & GACCAATCCAACCGAAACG (R) & $231 ; 236 ; 249$ & & & \\
\hline \multirow[t]{2}{*}{ Unmethylated allele } & GGATTGGGATGTTGAGAATG (F) & & 55 & 143 & \\
\hline & CAACCAATCCAACCAAAACAA (R) & & & & \\
\hline \multicolumn{6}{|c|}{ 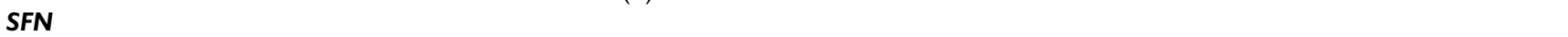 } \\
\hline \multirow[t]{2}{*}{ Methylated allele } & GGTAGTTTTTAATGAAAGGCGTC (F) & $153 ; 156$ & 56 & 106 & [33] \\
\hline & CCTCTAACCGCCCACCACG (R) & $219 ; 228$ & & & \\
\hline \multirow[t]{2}{*}{ Unmethylated allele } & ATGGTAGTTTTTATGAAAGGTGTT (F) & & 56 & 104 & \\
\hline & СССТСТАACCACCCACCACA (R) & & & & \\
\hline \multicolumn{6}{|l|}{ RASSFIA } \\
\hline \multirow[t]{2}{*}{ Methylated allele } & GGGTTTTGCGAGAGCGCG (F) & $-66 ;-60 ;-58$ & 55 & 169 & [45] \\
\hline & GCTAACAAACGCGAACCG (R) & $77 ; 82 ; 84 ; 94$ & & & \\
\hline \multirow[t]{2}{*}{ Unmethylated allele } & GGTTTTGTGAGAGTGTGTTTAG (F) & & 55 & 169 & \\
\hline & CACTAACAAACACAAACCAAAC (R) & & & & \\
\hline
\end{tabular}

MSP - Methylation-Specific Polymerase Chain Reaction; MS - methylation status; * in relation to transcription start site; Ta - Annealing temperature; bp - base pair; F- forward primer; $\mathrm{R}$ - reverse primer. 


\section{Results \\ MSP analysis in cell lineages}

MSP analysis of DNA from 5637 and T24 cell lines evidenced hypermethylation at the CDH1 and RASSF1A gene promoter regions. None of them showed this pattern for the RARB gene. The methylation of SFN was observed in 5637 cells, but was not present in T24.

\section{MSP analysis in matched tumoral and adjacent bladder tissue samples}

Fifty-four matched tumoral and adjacent tissue samples were collected. Remarkably, after histopathology, the presence of normal epithelial cell layer in normal adjacent biopsies was confirmed in only 14 pairs. Thus, MSP analysis was performed on 49 UCs obtained from unrelated patients, 14 of them matched with normal tissue samples, 3 squamous cell carcinomas and 2 adenocarcinomas. Table 2 summarizes the relevant clinical and histopathological characteristics in the group of 49 UC patients. On average, these patients received 30 months of follow-up monitoring. Twenty-five UC patients showed recurrence: $20(40.8 \%)$ were recurrent at the moment of the study sample collection, since they had a positive history of previous UC confirmed by a histological diagnosis before the date of the most recent surgery ( 0.7 to 7.5 years); and 5 had their primary tumor evaluated, but exhibited recurrence within a short time period (Table 3 ).

After genomic DNA treatment with sodium bisulfite and MSP analysis, both amplicons for unmethylated and methylated alleles, respectively, were detected in $\mathrm{CDH} 1$ and SFN gene target regions in all 49 fresh UC samples. Among histopathologically normal tumor-adjacent urinary bladder tissues, the same methylation pattern was found, except in one sample which showed only the unmethylated alleles for SFN gene.

Table 2: Clinical and histopathological data from patients with UC tumors.

\begin{tabular}{lc}
\hline \multicolumn{2}{l}{ Clinical and histopathological features } \\
\hline Patients, $\mathbf{n}$ & \\
Sex, $\mathbf{n}(\%)$ & 49 \\
Male & $40(81.6 \%)$ \\
Female & $9(18.4 \%)$ \\
Age, $\mathbf{n}(\%)$ & \\
$\leq 60$ years & $9(18.7 \%)$ \\
$>60$ years & $39(81.3 \%)$ \\
Growth pattern, $\mathbf{n}(\%)$ & \\
Papillary & $33(67.3 \%)$ \\
Non-papillary & $16(32.7 \%)$ \\
Muscle invasion, $\mathbf{n}(\%)$ & \\
Noninvasive & $30(61.2 \%)$ \\
Invasive & $19(38,8 \%)$ \\
\hline
\end{tabular}

* 48 patients contributed to this information
$R A R B$ and RASSF1A hypermethylation were detected in $40(81.6 \%)$ and $11(22.5 \%)$ UC samples, respectively. The comparison of 14 matched normal and tumoral urinary bladder samples exhibited a concordant pattern for presence of $R A R B$ hypermethylation in 12 pairs; in two pairs (cases 12 and 42, Figure 1) RARB hypermethylation was restricted to normal tissue. Absence of RASSF1A hypermethylation was a common feature in 9 bladder tissue pairs. Only one case showed hypermethylation in both normal and tumoral tissues (case 11, Figure 1) and, in 3 matched samples (cases 22, 29 and 36, Figure 1) it was restricted to the tumor specimens. Adjusted ORs for these data as well as demographic, physician and histopathological parameters related to the RARB and RASSF1A DNA methylation patterns in 49 UC samples are shown in Table 3.

The adenocarcinomas analyzed showed hypermethylation for both, RARB and RASSF1A genes. Two of the squamous cell carcinomas showed the same methylation pattern for $R A R B$, and one for RASSF1A.

\section{MSP analysis in exfoliated cells (bladder washings) in cancer-free controls and in bladder cancer patients} In the control group, of the 24 urinary bladder exfoliated cell samples submitted to cytological analysis from patients (median age of 61.4, ranging from 26 to 82 years) with negative diagnosis for cancer (four of them with cystitis), 2/23 (8.3\%) and 8/16 (50\%) exhibited RARB and RASSF1A hypermethylation, respectively. In addition, higher frequencies of methylation were detected for CDH1 (91.3\%) and SFN (95.5\%) genes. Compared to the results shown by the biopsy analysis of UCs, RARB had a sensitivity of $95 \%$ and specificity of $71 \%$ by Fisher's Exact test $(\mathrm{p}<0.0001$; OR = 48.89); for the same parameters, RASSF1A showed $58 \%$ and $17 \%$, respectively ( $<<0.05$; OR $=0.29$ ) (Table 4).

In the third sample set, hypermethylation identified in tumor DNA from archival UC samples was used as a molecular tag to predict tumor recurrence in the corresponding DNA obtained from cells of urinary bladder washings from UC patients under post-surgical monitoring. The comparative analysis between MSP from washout cells and corresponding primary and/or recurrence tumor sample was done for RARB and RASSF1A genes, including 23 urinary bladder washings and 39 paraffin-embedded UC samples from 20 patients (median age of 68.65, ranging from 42 to 84 years) (Figure 2). Among 39 tissue samples, RARB hypermethylation was identified in $14 / 38$ fragments $(36.8 \%)$ analyzed. Twelve patients showed at least one tumor fragment hypermethylated for $R A R B$ gene. Due to limited tissue volume, RASSF1A gene was analyzed in a subset of 15 fragments from 11 patients, 
Table 3: Clinical and histopathological prevalence parameters and DNA methylation pattern for RARB and RASSFIA genes in 49 fresh urinary bladder carcinoma tissues.

\begin{tabular}{|c|c|c|c|c|c|c|}
\hline \multirow[t]{2}{*}{ Variable } & \multicolumn{2}{|c|}{ RARB } & \multirow[t]{2}{*}{ OR (95\% Cl) } & \multicolumn{2}{|c|}{ RASSFIA } & \multirow[t]{2}{*}{ OR (95\% Cl) } \\
\hline & $\mathbf{N}(\mathbf{a})$ & $\mathbf{P}^{(a)}$ & & $N^{(a)}$ & $\mathbf{P}(\mathbf{a})$ & \\
\hline \multicolumn{7}{|l|}{ Age $\#$} \\
\hline$<60$ years & 1 & 8 & 1.0 (ref) & 6 & 3 & 1.0 (ref) \\
\hline$\geq 60$ years & 8 & 31 & $0.48(0.05-4.45)$ & 31 & 8 & $0.5 \mathrm{I}(0.10-2.52)$ \\
\hline \multicolumn{7}{|l|}{ Sex* } \\
\hline Female & 3 & 6 & $\mathrm{I} .0$ (ref) & 9 & 0 & na $p^{(1)}=0,097$ \\
\hline Male & 6 & 34 & $2.83(0.55-14.54)$ & 29 & 11 & \\
\hline \multicolumn{7}{|c|}{ Growth pattern*(b) } \\
\hline Non-papillary & 2 & 7 & 1.0 (ref) & 12 & 4 & $1.0($ ref) \\
\hline Papillary & 14 & 26 & $0.53(0.09-2.90)$ & 26 & 7 & $0.80(0.19-3.29)$ \\
\hline \multicolumn{7}{|c|}{ Differentiation grade $*(b)$} \\
\hline Low & 5 & 16 & 1.0 (ref) & 18 & 3 & 1.0 (ref) \\
\hline High & 4 & 24 & $1.88(0.44-8.07)$ & 20 & 8 & $2.40(0.55-10.46)$ \\
\hline \multicolumn{7}{|c|}{ Muscle invasion*(b) } \\
\hline Noninvasive & 7 & 23 & 1.0 (ref) & 24 & 6 & 1.0 (ref) \\
\hline Invasive & 2 & 17 & $2.59(0.48-14.05)$ & 14 & 5 & $1.43(0.37-5.55)$ \\
\hline \multicolumn{7}{|c|}{ Post-surgery recurrence* } \\
\hline Absence & $4(0 / 20)$ & $22^{(4 / 20)}$ & 1.0 (ref) & $19(3 / 20)$ & $7(1 / 20)$ & 1.0 (ref) \\
\hline Presence & $5(1 / 20)$ & $18(15 / 20)$ & $0.65(0.15-2.80)$ & $19(13 / 20)$ & $4(3 / 20)$ & $0.57(0.14-2.27)$ \\
\hline
\end{tabular}

\#Includes 48 samples; *Includes 49 samples; $\mathrm{N}$ - methylation negative; $\mathrm{P}$ - methylation positive; (a) patients that showed recurrence among those that were under recurrence at time of the tumor sample collection; (b) according to recommendations of WHO-ISUP I998 [43]; OR - odds ratio; $\mathrm{Cl}$ - confidence interval; ref - referent category; na - not applicable; (I) Fisher's Exact test $(\alpha=0.05)$.

with methylation detected in $9 / 15$ of them (60\%); these hypermethylated tumors were from 7 patients.

Patients showing at least one hypermethylated tumor fragment for RARB and/or RASSF1A were considered informative cases for further comparisons. The MSP results were challenged by cytological analysis during the post-surgical monitoring: 5/12 patients showed positive cytology at the time of cell collection to MSP analysis, but only one of these exhibited RARB hypermethylation in the same washout cells. MSP analysis results of RASSF1A gene in 7 informative patients were discordant because none of the 4 recurrent cases by cytological analysis showed the epigenetic marker; contrarily, RASSF1A hypermethylation was detected in 2 of the 3 non-recurrent cases. Table 5 exhibits the sensitivity and specificity of MSP analysis in relation to the gold-standard cytological evaluation for tumor recurrence detection.

\section{Discussion}

Epigenetic alterations are a hallmark of human cancer. In particular, DNA hypermethylation is a common mechanism for inactivating tumor-suppressor and other cancer genes in tumor cells [48]. The aberrant methylation patterns have been used as targets for the detection of tumor cells in clinical specimens such as tissue biopsies or body fluids [49].
In our MSP analysis performed on DNA obtained from fresh tumor samples, a hypermethylated pattern predominated for $C D H 1$ and SFN genes. Commonly, a large spectrum of hypermethylation frequencies has been reported for several genes in bladder cancer. For example, $\mathrm{CDH} 1$ gene methylation frequencies range from $9.5 \%$ to $84 \%$ $[15,22,25,27,30,37-40]$, independently of histological classification. We detected $C D H 1$ hypermethylation frequency of $100 \%$ in bladder UCs, squamous cell carcinomas and adenocarcinomas samples, as well as in normal adjacent urinary bladder tissue and in exfoliated urothelial cells from cancer-free controls. Similarly, the SFN gene was also hypermethylated in these samples. Costa et al. [50] also detected high frequencies of $C D H 1$ methylation in clear cell renal carcinomas and normal renal tissues ( $82.7 \%$ and $87.1 \%$, respectively); in addition, SFN was hypermethylated in $100 \%$ of normal and tumoral renal tissues analyzed.

Interpretation of differential DNA-methylation patterns in cancer has proven difficult, in part because the functional consequences depend on the genomic region involved, the specific CpG dinucleotides, and the interand intratumoral heterogeneity. Apart from this, methodological issues such as the different primer sets interrogating methylation at distinct $\mathrm{CpG}$ dinucleotides of a specific promoter region could explain the range of frequencies reported in the literature. In our study, the protocol used (which included the addition of urea in the DNA modifi- 


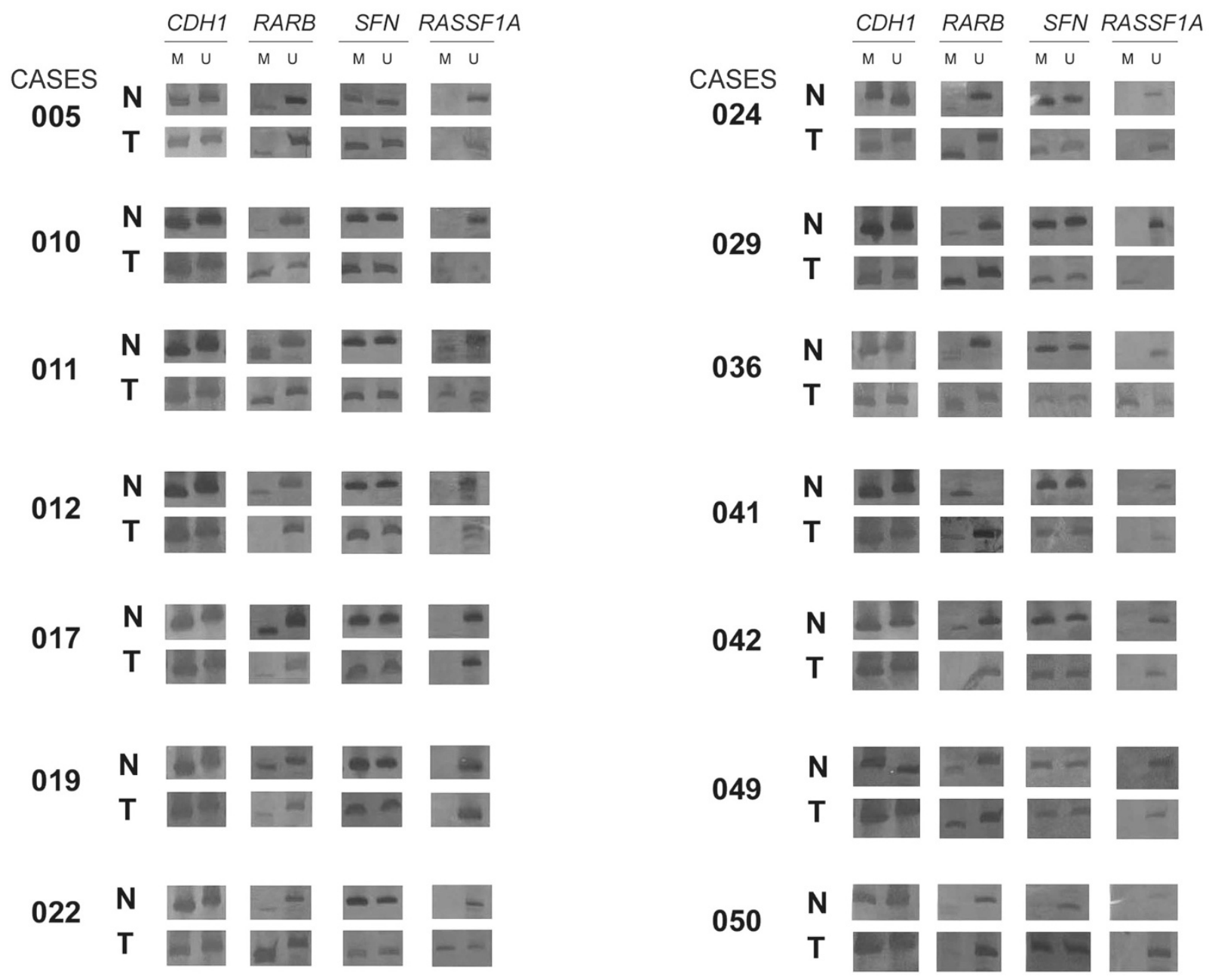

Figure I

CDHI, RARB, SFN andRASSFIAmethylation patterns observed in fresh UC samples paired with normal adjacent urinary bladder tissue. $\mathrm{M}$ - methylated allele; $\mathrm{U}$ - unmethylated allele; $\mathrm{N}$ - normal tissue; $\mathrm{T}$ - tumoral tissue.

cation step in order to improve the efficiency of unmethylated cytosine conversion [42]) and the CDH1 gene analysis based on the nested-PCR approach may have contributed to the high methylation prevalence observed.
The dynamic nature of epigenetic alterations is partially due to polymorphisms in some methyl group metabolism genes $[51,52]$ and in genes coding for proteins that mediate these changes (DNA methyltransferases, methyl-CpGbinding domain proteins) [53]. In addition, genomic pro-

Table 4: Accuracy patterns in urinary bladder tumor biopsies and control group bladder washings (cell sediment samples from bladder washings of patients classified as cancer-free by cytological analysis).

\begin{tabular}{|c|c|c|c|c|c|c|c|c|}
\hline \multirow[t]{3}{*}{ Sample } & \multicolumn{8}{|c|}{ Accuracy patterns (\%) } \\
\hline & \multicolumn{4}{|c|}{ RARB } & \multicolumn{4}{|c|}{ RASSFIA } \\
\hline & $\begin{array}{c}\text { OR } \\
(95 \% \mathrm{Cl})\end{array}$ & Sens. & Spec. & $\mathbf{p}^{(1)}$ & $\begin{array}{c}\text { OR } \\
(95 \% \mathrm{Cl})\end{array}$ & Sens. & Spec. & $\mathbf{p}^{(1)}$ \\
\hline Control group & 1.0 (ref) & $95 \%$ & $71 \%$ & 0.0001 & 1.0 (ref) & $58 \%$ & $17 \%$ & 0.005 \\
\hline Tumor biopsies & 48.89 (9.69-246.67) & & & & $0.29(0.09-0.95)$ & & & \\
\hline
\end{tabular}

Sens. - Sensitivity; Spec. - Specificity; ref - referent category; Cl - confidence interval; (I) Fisher's Exact test $(\alpha=0.05)$ 

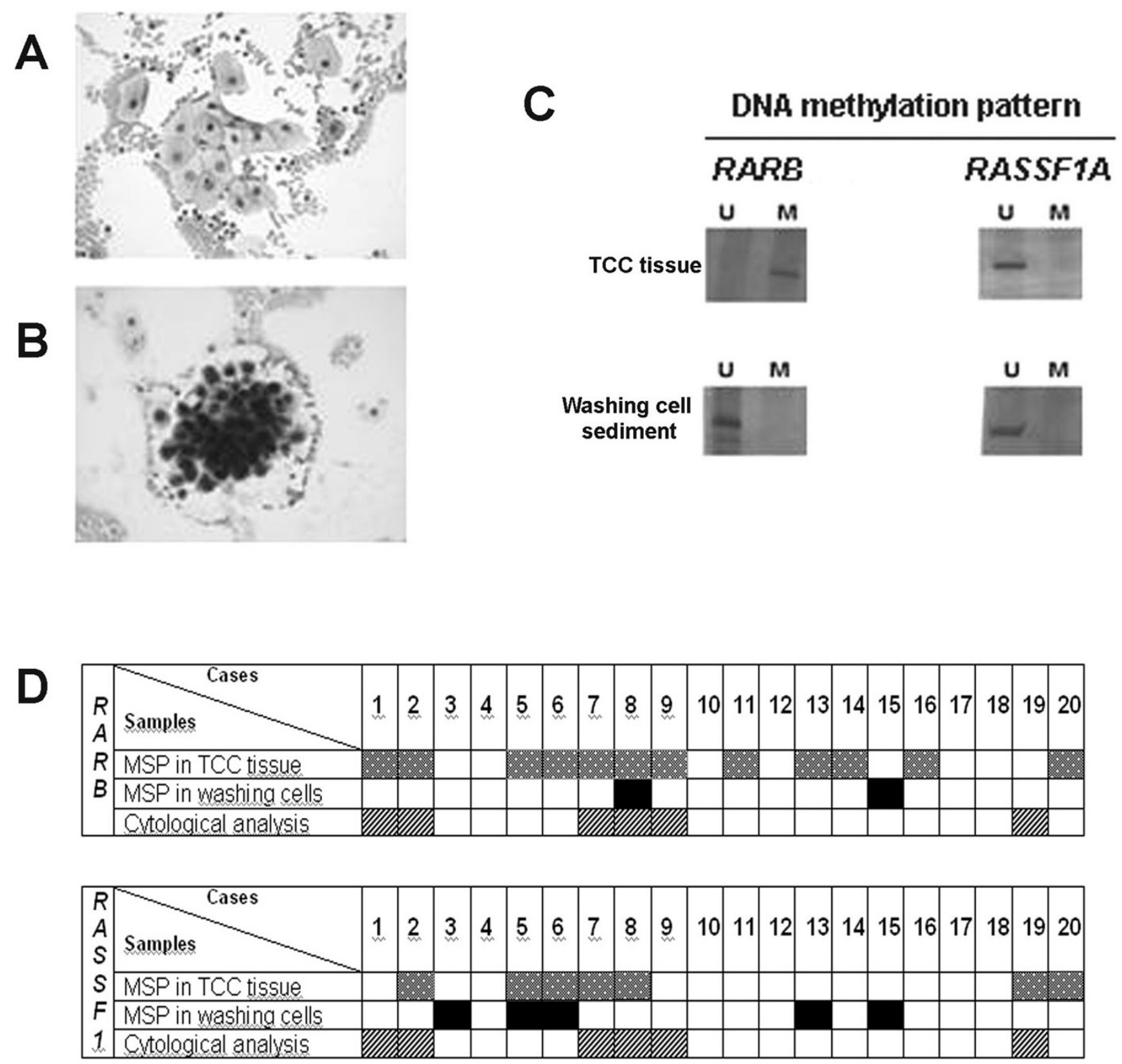

Legend:

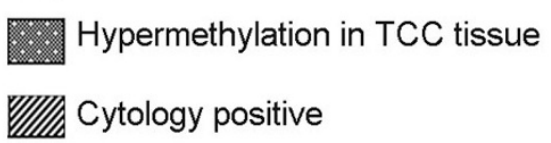

Hypermethylation in matched washing cells

Absence of hypermethylation / cytology negative

\section{Figure 2}

A) Cytological analysis of bladder washing sediment negative for the presence of tumor cells (case II). B) Positive cytology illustrating a tumor recurrent case during the post-surgical monitoring. $\times 400$, Giemsa staining. C) Comparative MSP results from case II in tumor tissue (TCC) and in the exfoliated cells from the correspondent bladder washing for RARB and RASSFIA genes. M - methylated allele; $U$ - unmethylated allele. D) Distribution of MSP results among the third set of samples including 39 archived tumor fragments and 23 matched washouts from 20 urinary bladder cancer patients in post-surgical monitoring and comparison with the cytological analysis. 
Table 5: Accuracy estimatives from MSP for RARB and RASSFIA genes observed in primary and/or previous recurrence of urinary bladder carcinoma and respective washout.

\begin{tabular}{|c|c|c|c|c|c|}
\hline \multirow[t]{2}{*}{ Gene } & \multicolumn{5}{|c|}{ Accuracy patterns (\%) } \\
\hline & Sensitivity & Specificity & PPV & NPV & $\mathbf{p}^{(1)}$ \\
\hline \multicolumn{6}{|c|}{ Sediment of washout cells } \\
\hline RARB & $1 / 6(16.7)$ & $13 / 14(92.8)$ & $\mathrm{I} / 2(50.0)$ & $13 / 18(72.2)$ & 0.521 \\
\hline RASSFIA & $0 / 4(0.00)$ & $5 / 10(50.0)$ & $0 / 5(0.00)$ & $5 / 9(55.5)$ & 0.220 \\
\hline \multicolumn{6}{|c|}{ Fixed and paraffin-embedded bladder cancer tissue } \\
\hline RARB & $5 / 6(83.3)$ & $7 / 14(50.0)$ & $5 / 12(41.6)$ & $7 / 8(87.5)$ & 0.324 \\
\hline RASSFIA & $4 / 4(100.0)$ & $4 / 7(57.1)$ & $4 / 7(57.1)$ & $4 / 4(100.0)$ & 0.193 \\
\hline
\end{tabular}

Cytology results were used as reference to detect the recurrence.

(I) Fisher's Exact test $(\alpha=0.05)$; PPV - positive predictive value; NPV - negative predictive value

files of DNA methylation are also influenced by aging $[38,54]$, dietary intake $[55,56]$ and environmental exposure $[53,57,58]$. In this context, DNA methylation heterogeneous patterns should be expected and already detected for some genomic regions as reported by Eckkhardt et al. [59]. These authors have found that $30.2 \%$ of investigated loci on chromosomes 6,20 , and 22 exhibit heterogeneity of methylation status, mainly due to the mosaic patterns in the studied tissue. Furthermore, 10\% of the analyzed regions showed tissue-specific differences in DNA methylation.

We observed hypermethylated CDH1, SFN, and RARB genes in the normal-adjacent tissue of urinary bladder tumor. Aberrant methylation patterns have been associated with chronic inflammation $[60,61]$, viral infection [62] and aging [63]. Smith and Pereira-Smith [64] have previously reported that epigenetic alterations are involved in both the etiology and consequences of aging. Thus, hypermethylation in normal tissue as detected in the present study agrees with the results previously found by Bornman et al. [38], who observed a similar pattern for CDH1 in normal bladder tissue from patients older than 70 years. Furthermore, aberrant methylation patterns of the $C D H 1$ promoter region were also described in preadenoma stages of colorectal cancer, in hyperplasic polyps $[65,66]$ and in ulcerative colitis (a chronic inflammatory condition of the large intestine that predisposes to cancer) $[60,67]$. During breast cancer progression, $C D H 1$ gene methylation occurs in about $30 \%$ of the ductal carcinomas in situ, with a significant increase in invasive and metastatic lesions [68]. Moreover, this gene has been also found methylated in pre-malignant and invasive bladder cancers. In mammary tissue, SFN is usually unmethylated in normal epithelium, but methylated in atypical hyperplasias, intraductal papillomas, ductal in situ carcinomas, infiltrating carcinomas and in stromal cells $[69,70]$. SFN and $C D H 1$ methylation have been reported in peripheral blood cells [70] as well as in infiltrating leukocytes in breast cancer [71]. Overall, these observations suggest that both genes, CDH1 and SFN, are not effective biomarkers for MSP analysis in bladder cancer.

The MSP analysis of RARB and RASSF1A genes showed respective hypermethylation of $82.9 \%$ and $24.4 \%$ in 49 UCs analyzed. Investigating the methylation at the same CpG dinucleotides, Maruyama et al. [22], and Catto et al. [25], found $15 \%$ and $24 \%$ hypermethylation for RARB, and $35 \%$ and $54 \%$ for RASSF $1 A$, respectively. In order to verify the specificity of RARB and RASSF1A hypermethylation in relation to malignant phenotype in bladder tissue, we evaluated these genes in exfoliated urothelial cells from patients without cancer (control group): RARB and RASSF1A hypermethylation were detected in $8.3 \%$ and $33.3 \%$, respectively. The comparison of these data revealed that $R A R B$ hypermethylation provides better diagnostic coverage and specificity than RASSF1A hypermethylation. However, the hypermethylated pattern of these genes in normal adjacent tissue in matched samples, especially for the RARB gene, was an unexpected finding. In this context, we could hypothesize that molecular alterations precede morphological changes in the exposed urinary bladder epithelium, since patients with bladder neoplasia frequently show genetic instability on apparently normal mucosa besides alterations of surrounding tissue [72]. Aberrant methylation patterns appear to reflect a pre-malignant characteristic of the urinary bladder mainly because UC is a neoplasia with multifocal lesions and elevated recurrence indices [73], thus corroborating the hypothesis that epigenetic alterations in cancer may preexist in morphologically normal cells [74].

Thus, genetic and epigenetic alterations may be present before cancer detection by imaging or traditional pathology investigations. Therefore, molecular tests that target these alterations have conceptual advantages for the suc- 
cessful early detection of neoplasias [48]. DNA represents an ideal substrate for molecular detection because it is robust, survives adverse conditions that many clinical specimens undergo and, can be readily amplified by powerful PCR-based approaches [75]. Tiny amounts of DNA from early pre-neoplastic lesions or small cancers can be used to permit the sensitive detection of one cancer cell in a background of hundreds of normal cells.

Hence, the predictive value of MSP in identifying tumor cells in washing sediments was evaluated in bladder cancer patients under post-surgical monitoring to detect tumor recurrence. Positive cytology was found in $33.3 \%$ of patients with urinary bladder tumor history. The hypermethylation patterns of RARB and RASSF1A genes observed in cells obtained from urinary bladder washing sediments were not concordant: some hypermethylated cases in tumor tissue and recurrence by cytological analysis did not show this marker in the same exfoliated cells. Contrarily, in four cases, the cells taken from urinary bladder washings exhibiting hypermethylation for these genes did not match the hypermethylation of the correspondent TCC. The heterogeneity of the intra- and intertumoral methylation patterns could partially explain these discrepancies. Thus, hypermethylation could already be present in the urinary bladder epithelium of cancer patients but not necessarily in cells exfoliated from the urinary bladder of cancer-free patients. RARB hypermethylation confirmed the presence of tumor cells in only 1 out of 5 recurrent cases and was absent in all cases showing negative cytology. Importantly, for the eight patients whose tumors did not present RARB methylation, the paired cell washing sediments DNA were also negative for methylation. This finding corroborates the idea that the methylation pattern of this gene is specific for tumor cells. RASSF1A gene MSP analysis in washout cells showed discordant results since its hypermethylation was not detected in 4 recurrent cases, although 2 negative cases for tumor cells using cytology showed this tumor tag, which suggest that these patients are under high risk for tumor recurrence. Some studies using promoter hypermethylation identified in tumor DNA as a target for cancer detection in the correspondent urine sample have shown sensitivities ranging from $49 \%$ to $91 \%[15,26,30,75]$. Recently, Yu et al. [76] included the RASSF1A in an 11-gene set to assessment of DNA methylation in urine sediments for sensitive/specific detection of bladder cancer. Although two studies have reported that the overall methylation sensitivity was significantly higher than cytology $[15,77]$, several factors may contribute to the lower sensitivities of MSP analysis in cells from urinary bladder fluids including the incomplete diagnostic coverage of selected gene sets, limited quantity of cells sampled, and the intrinsic heterogeneity of methylation patterns in the exposed epithelium, among others.

\section{Conclusion}

In the literature, no single gene was found to be consistently methylated in most bladder tumors. Thus, panels of genes that are methylated in urinary bladder cancer have been investigated to define methylation profiles associated with urinary bladder cancer diagnosis, prognosis and early recurrence detection. DNA hypermethylation of CDH1 and SFN genes was detected indistinctly among urinary bladder tumoral and normal tissues as well as in urinary bladder exfoliated cells, suggesting that these epigenetic features do not satisfy enough specificity criteria for use as prognostic or early detection markers. The methylation of RARB and RASSF1A genes appears to be an initial event in urinary bladder carcinogenesis maintained during tumor progression and should be included in the panels of differentially methylated genes in urinary bladder cancer in order to maximize the diagnostic coverage of epigenetic markers.

\section{Abbreviations}

CDH1: cadherin 1, type 1, E-cadherin [epithelial] gene; $L O H$ : loss of heterozygosity; MSP: methylation-specific PCR; RARB: retinoic acid receptor, beta gene; RASSF1A: Ras association (RalGDS/AF-6) domain family 1 gene;

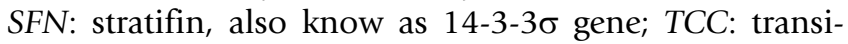
tional cell carcinoma; TSG: tumor suppressor gene; UC: urothelial carcinoma.

\section{Competing interests}

The authors declare that they have no competing interests.

\section{Authors' contributions}

PDN assisted in the study design, in defining the casuistic used, in collecting fresh bladder samples, carrying out the molecular genetic studies and performing the statistical analysis. CAR assisted in the study design, in defining the casuistic used, carrying out the molecular genetic studies and performing the statistical analysis. FPF carried out the molecular genetic studies. JLVC performed the histopathological analysis and classified all fresh bladder samples. MLCSO carried out the cytological analysis of all urinary bladder washings. JG collected urinary bladder washing samples. DMFS was responsible for the study coordination, assisted in the design of the study and in defining the casuistic used. All authors helped to draft the manuscript, and to read and approve the final version.

\section{Acknowledgements}

To the staff at Amaral Carvalho Hospital, Jaú, SP, Brazil for the agreement to contribute to this study, especially to Dr. Renato Costa Prado from the Department of Urology; Dr. Adauto José Ferreira Nunes and Dr. Francisco Carlos Quevedo from the Department of Pathology. To João Paulo de Castro Marcondes, Merielen Garcia Nascimento and Bruna Liboni for other contributions. PDN was supported by grants from Fundação de Amparo à Pesquisa do Estado de São Paulo (FAPESP 03/I I730-8). This study was financially supported by Fundação de Amparo à Pesquisa do Estado de São 
Paulo (FAPESP 04/00 108-7) and Conselho Nacional de Desenvolvimento Científico e Tecnológico (CNPq).

\section{References}

I. Kirkali Z, Chan T, Manoharan M, Algaba F, Bush C, Cheng L, Kiemeney L, Kriegmair M, Montinroni R, Murphy WM, Sesterhenn IA, Tachibana M, Weider J: Bladder Cancer: Epidemiology, staging and grading, and diagnosis. Urology 2005, 66:4-34.

2. Reuter VE: The pathology of bladder cancer. Urology 2006, 67: II-I7.

3. Knowles MA: Tumor suppressor loci in bladder cancer. Front Biosci 2007, I 2:2233-225I.

4. Christoph F, Weikert S, Kempkensteffen C, Krause H, Schostak M, Miller K, Schrader M: Regularly methylated novel pro-apoptotic genes associated with recurrence in transitional cell carcinoma of the bladder. Int J Cancer 2006, I I 9: | 396-|402.

5. Blaveri E, Simko JP, Korkola JE, Brewer JL, Baehner F, Mehta K, Devries S, Koppie T, Pejavar S, Carroll P, Waldman FM: Bladder cancer outcome and subtype classification by gene expression. Clin Cancer Res 2005, I I:4044-4055.

6. Bartoletti R, Cai T, Nesi G, Roberta Girardi L, Baronti G, Dal Canto M: Loss of PI6 Expression and Chromosome 9p2I LOH in Predicting Outcome of Patients Affected by Superficial Bladder Cancer. J Surg Res 2007, I 43:422-427.

7. Leonardo C, Merola R, Orlandi G, Leonardo F, Rondoni M, De Nunzio $C$ : C-erb-2 gene amplification and chromosomal anomalies in bladder cancer: preliminary results. J Exp Clin Cancer Res 2005, 24:633-638.

8. Cho HY, Park HS, Lin Z, Kim I, Joo KJ, Cheon J: BCL6 gene mutations in transitional cell carcinomas. J Int Med Res 2007, 35:224-230.

9. Turyn J, Matuszewski M, Schlichtholz B: Genomic instability analysis of urine sediment versus tumor tissue in transitional cell carcinoma of the urinary bladder. Oncol Rep 2006, I5:259-265.

10. Baylin SB, Ohm JE: Epigenetic gene silencing in cancer - a mechanism for early oncogenic pathway addiction? Nat Rev Cancer 2006, 6:107-116.

II. Herman JG, Graff JR, Myohanen S, Nelkinm BD, Baylin SB: Methylation-specific PCR: a novel PCR assay for methylation status of CpG islands. Proc Natl Acad Sci USA 1996, 93:982I-9826.

12. Turker MS, Bestor TH: Formation of methylation patterns in the mammalian genome. Mutat Res 1997, 386:1 19-130.

13. Jones PA, Baylin SB: The fundamental role of epigenetic events in cancer. Nat Rev Genet 2002, 3:4I5-428.

14. Lodygin D, Epanchintsev A, Menssen A, Diebold J, Hermeking $\mathrm{H}$ : Functional epigenomics identifies genes frequently silenced in prostate cancer. Cancer Res 2005, 65:4218-4227.

15. Chan MW, Chan LW, Tang NL, Tong JH, Lo KW, Lee TL, Cheung HY, Wong WS, Chan PS, Lai FM, To KF: Hypermethylation of multiple genes in tumor tissues and voided urine in urinary bladder cancer patients. Clin Cancer Res 2002, 8:464-470.

16. Esteller M: CpG island hypermethylation and tumor suppressor genes: a booming present, a brighter future. Oncogene 2002, 2 I:5427-5440.

17. Horikawa Y, Sugano K, Shigyo M, Yamamoto H, Nakazono M, Fujimoto H, Kanai Y, Hirohashi S, Kakizoe T, Habuchi T, Kato T: Hypermethylation of an E-cadherin (CDHI) promoter region in high grade transitional cell carcinoma of the bladder comprising carcinoma in situ. J Urol 2003, I 69:I54 I-I545.

18. Tzai TS, Chen HH, Chan SH, Ho CL, Tsai YS, Cheng HL, Dai YC, Lin JS, Yang WH, Chow NH: Clinical significance of allelotype profiling for urothelial carcinoma. Urology 2003, 62:378-384.

19. Zhang J, Zheng S, Gao Y, Rotolo JA, Xiao Z, Li C, Cheng S: A partial allelotyping of urothelial carcinoma of bladder in the Chinese. Carcinogenesis 2004, 25:343-347.

20. Weinberg RA: Tumor supressor genes. Science 1991, 254: I | 38-I| 46 .

21. Hoque MO, Lee CC, Cairns P, Schoenberg M, Sidransky D: Genome-wide genetic characterization of bladder cancer: a comparison of high-density single-nucleotide polymorphism arrays and PCR-based microsatellite analysis. Cancer Res 2003, 63:2216-2222

22. Maruyama R, Toyooka S, Toyooka KO, Harada K, Virmani AK, Zöchbauer-Müller S, Farinas AJ, Vakar-Lopez F, Minna JD, Sagalowsky A, Czerniak B, Gazdar AF: Aberrant promoter methylation profile of bladder cancer and its relationship to clinicopathological features. Cancer Res 200 I, 6 I:8659-8663.

23. Chan MW, Chan LW, Tang NL, Lo KW, Tong JH, Chan AW, Cheung HY, Wong WS, Chan PS, Lai FM, To KF: Frequent hypermethylation of promoter region of RASSFIAA in tumor tissues and voided urine of urinary bladder cancer patients. Int J Cancer 2003, I 04:6II-6I6.

24. Gutierrez MI, Siraj AK, Khaled H, Koon N, El-Rifai W, Bhatia K: CpG island methylation in Schistosoma- and non-Schistosomaassociated bladder cancer. Mod Pathol 2004, I 7:। 268-1274.

25. Catto JW, Azzouzi AR, Rehman I, Feeley KM, Cross SS, Amira N, Fromont G, Sibony M, Cussenot O, Meuth M, Hamdy FC: Promoter hypermethylation is associated with tumor location, stage, and subsequent progression in transitional cell carcinoma. Clin Oncol 2005, 23:2903-29I0.

26. Friedrich MG, Weisenberger DJ, Cheng JC, Chandrasoma S, Siegmund KD, Gonzalgo ML, Toma MI, Huland $\mathrm{H}$, Yoo C, Tsai YC, Nichols PW, Bochner BH, Jones PA, Liang G: Detection of methylated apoptosis-associated genes in urine sediments of bladder cancer patients. Clin Cancer Res 2004, I 0:7457-7465.

27. Friedrich MG, Chandrasoma S, Siegmund KD, Weisenberger DJ, Cheng JC, Toma MI, Huland H, Jones PA, Liang G: Prognostic relevance of methylation markers in patients with non-muscle invasive bladder carcinoma. Eur J Cancer 2005, 41:2769-2778.

28. Dammann R, Schagdarsurengin U, Seidel C, Strunnikova M, Rastetter M, Baier K, Pfeifer GP: The tumor suppressor RASSFIA in human carcinogenesis: an update. Histol Histopathol 2005, 20:645-663.

29. Marsit CJ, Karagas MR, Danaee H, Liu M, Andrew A, Schned A, Nelson $\mathrm{HH}$, Kelsey KT: Carcinogen exposure and gene promoter hypermethylation in bladder cancer. Carcinogenesis 2006, 27:1 12-116.

30. Hoque MO, Begum S, Topaloglu O, Chatterjee A, Rosenbaum E, Van Criekinge W, Westra WH, Schoenberg M, Zahurak M, Goodman SN, Sidransky D: Quantitation of promoter methylation of multiple genes in urine DNA and bladder cancer detection. J Natl Cancer Inst 2006, 98:996-1004.

31. Soprano DR, Qin P, Soprano KJ: Retinoic acid receptors and cancers. Annu Rev Nutr 2004, 24:201-22I.

32. Brtko J: Role of retinoids and their cognate nuclear receptors in breast cancer chemoprevention. Cent Eur J Public Health 2007, I 5:3-6.

33. Ferguson AT, Evron E, Umbricht CB, Pandita TK, Chan TA, Hermeking $H$, Marks JR, Lambers AR, Futreal A, Stampfer MR, Sukumar S: High frequency of hypermethylation at the 14-3-3 sigma locus leads to gene silencing in breast cancer. Proc Natl Acad Sci USA 2000, 97:6049-6054.

34. Kunze E, Wendt M, Schlott T: Promoter hypermethylation of the I4-3-3 sigma, SYK and CAGE-I genes is related to the various phenotypes of urinary bladder carcinomas and associated with progression of transitional cell carcinomas. Int J Mol Med 2006, I 8:547-557.

35. Hirohashi S, Kanai Y: Cell adhesion system and human cancer morphogenesis. Cancer Sci 2003, 94:575-58I.

36. Qian ZR, Sano T, Yoshimoto K, Asa SL, Yamada S, Mizusawa N, Kudo $E:$ Tumor-specific downregulation and methylation of the CDHI3 (H-cadherin) and CDHI (E-cadherin) genes correlate with aggressiveness of human pituitary adenomas. Mod Pathol 2007, 20:1269-I277.

37. Dhawan D, Hamdy FC, Rehman I, Patterson J, Cross SS, Feeley KM, Stephenson Y, Meuth M, Catto JW: Evidence for the early onset of aberrant promoter methylation in urothelial carcinoma. J Pathol 2006, 209:336-343.

38. Bornman DM, Mathew S, Alsruhe J, Herman JG, Gabrielson E: Methylation of the E-cadherin gene in bladder neoplasia and in normal urothelial epithelium from elderly individuals. $A m J$ Pathol 200I, I 59(3):83I-835.

39. Ribeiro-Filho LA, Franks J, Sasaki M, Shiina H, Li L-C, Nojima D, Arap S, Carroll P, Enokida H, Nakagawa M, Yonezawa S, Dahiya R: CpG hypermethylation of promoter region and inactivation of $E$ cadherin gene in human bladder cancer. Mol Carcinog 2002, 34:187-198.

40. Horikawa Y, Sugano K, Shigyo M, Yamamoto H, Nakazono M, Fujimoto H, Kanai Y, Hirohashi S, Kakizoe T, Habuchi T, Kato T: Hypermethylation of an E-cadherin (CDHI) promoter region in 
high grade transitional cell carcinoma of the bladder comprising carcinoma in situ. J Urol 2003, 169:154I-1545.

41. Epstein JI, Amin MB, Reuter VR, Mostofi FK: The World Health Organization/International Society of Urological Pathology Consensus Classification of Urothelial (Transitional Cell) Neoplasms of the Urinary Bladder. Bladder Consensus Conference Committee. Am J Surg Path 1998, 22: |435-| 448.

42. Paulin R, Grigg GW, Davey MW, Piper AA: Urea improves efficiency of bisulphite-mediated sequencing of 5'-methylcytosine in genomic DNA. Nucleic Acids Res 1998, 26:5009-5010.

43. Corn PG, Heath EI, Heitmiller R, Fogt F, Forastiere AA, Herman JG, $\mathrm{Wu}$ TT: Frequent hypermethylation of the $\mathbf{5}^{\prime} \mathrm{CpG}$ island of $\mathrm{E}-$ cadherin in esophageal adenocarcinoma. Clin Cancer Res 200I, 7:2765-2769.

44. Evron E, Dooley WC, Umbricht CB, Rosenthal D, Sacchi N, Gabrielson E, Soito AB, Hung DT, Ljung B-M, Davidson NE, Sukumar S: Detection of breast cancer cells in ductal lavage fluid by methylation-specific PCR. Lancet 200I, 357:1335-1336.

45. Burbee DG, Forgacs E, Zochbauer-Muller S, Shivakumar L, Fong K, Gao B, Randle D, Kondo M, Virmani A, Bader S, Sekido Y, Latif F, Milchgrub S, Toyooka S, Gazdar AF, Lerman MI, Zabarovsky E, White $M$, Minna JD: Epigenetic inactivation of RASSFIA in lung and breast cancers and malignant phenotype suppression. I Nat Cancer Inst 200I, 93:691-699.

46. Caldeira JR, Prando EC, Quevedo FC, Neto FA, Rainho CA, Rogatto SR: CDHI promoter hypermethylation and E-cadherin protein expression in infiltrating breast cancer. BMC Cancer 2006, 6:48.

47. Sanguinetti CJ, Dias Neto E, Simpson AJG: Rapid silver staining and recovery of $P C R$ products separated on polyacrylamide gels. BioTech 1994, I7:914-921.

48. Cairns P: Gene methylation and early detection of genitourinary cancer: the road ahead. Nat Rev Cancer 2007, 7:53 I-543

49. Sidransky D: Emerging molecular markers of cancer. Nat Rev Cancer 2002, 2:210-219.

50. Costa VL, Henrique R, Ribeiro FR, Pinto M, Oliveira J, Lobo F, Teixeira MR, Jerónimo C: Quantitative promoter methylation analysis of multiple cancer-related genes in renal cell tumors. BMC Cancer 2007, 7: 133.

5I. Chan EC, Lam SY, Fu KH, Kwong YL: Polymorphisms of the GSTMI, GSTPI, MPO, XRCCI, and NQOI genes in Chinese patients with non-small cell lung cancers: relationship with aberrant promoter methylation of the CDKN2A and RARB genes. Cancer Genet Cytogenet 2005, 162:10-20.

52. Kang S, Kim JW, Kang GH, Park NH, Song YS, Kang SB, Lee HP. Polymorphism in folate- and methionine-metabolizing enzyme and aberrant CpG island hypermethylation in uterine cervical cancer. Gynecol Oncol 2005, 96:173-180.

53. Miremadi A, Oestergaard MZ, Pharoah PD, Caldas C: Cancer genetics of epigenetic genes. Hum Mol Genet 2007, I 6(Spec No I):R28-49.

54. Kwabi-Addo B, Chung W, Shen L, Ittmann M, Wheeler T, Jelinek J, Issa JP: Age-related DNA methylation changes in normal human prostate tissues. Clin Cancer Res 2007, 1 3:3796-3802.

55. Feil R: Environmental and nutritional effects on the epigenetic regulation of genes. Mutat Res 2006, 600:46-57.

56. Waterland RA: Assessing the effects of high methionine intake on DNA methylation. J Nutr 2006, 136: 1706S-1710S

57. Bollati V, Baccarelli A, Hou L, Bonzini M, Fustinoni S, Cavallo D, Byun HM, Jiang J, Marinelli B, Pesatori AC, Bertazzi PA, Yang AS: Changes in DNA methylation patterns in subjects exposed to lowdose benzene. Cancer Res 2007, 67:876-880.

58. Sathyanarayana UG, Moore AY, Li L, Padar A, Majmudar K, Stastny V, Makarla P, Suzuki M, Minna JD, Feng Z, Gazdar AF: Sun exposure related methylation in malignant and non-malignant skin lesions. Cancer Lett 2007, 245: I I2-120.

59. Eckhardt F, Lewin J, Cortese R, Rakyan VK, Attwood J, Burger M, Burton J, Cox TV, Davies R, Down TA, Haefliger C, Horton R, Howe K, Jackson DK, Kunde J, Koenig C, Liddle J, Niblett D, Otto T, Pettett R, Seemann S, Thompson C, West T, Rogers J, Olek A, Berlin K, Beck S: DNA methylation profiling of human chromosomes 6, 20 and 22. Nat Genet 2006, 38:1378-1385.

60. Hsieh C], Klump B, Holzmann K, Borchard F, Gregor M, Porschen R: Hypermethylation of the pI6INK4a promoter in colectomy specimens of patients with long-standing and extensive ulcerative colitis. Cancer Res 1998, 58:3942-3945.
6I. Issa JP, Ahuja N, Toyota M, Bronner MP, Brentnall TA: Accelerated age-related CpG island methylation in ulcerative colitis. Cancer Res 200I, 6 I:3573-3577.

62. Kang GH, Lee S, Kim WH, Lee HW, Kim JC, Rhyu MG, Ro JY: Epstein-barr virus-positive gastric carcinoma demonstrates frequent aberrant methylation of multiple genes and constitutes CpG island methylator phenotype-positive gastric carcinoma. Am J Pathol 2002, 160:787-794.

63. Waki T, Tamura G, Sato M, Motoyama T: Age-related methylation of tumor suppressor and tumor-related genes: an analysis of autopsy samples. Oncogene 2003, 22:4I $28-4 \mid 33$.

64. Smith JR, Pereira-Smith OM: Replicative senescence: implications for in vivo aging and tumor suppression. Science 1996, 273:63-67.

65. Chan AO, Broaddus RR, Houlihan PS, Issa Jp, Hamilton SR, Rashid A CpG island methylation in aberrant crypt foci of the colorectum. Am J Pathol 2002, 160:1823-1830.

66. Jass JR, Young J, Leggett BA: Evolution of colorectal cancer: change of pace and change of direction. J Gastroenterol Hepatol 2002, I7:17-26.

67. Azarschab P, Porschen R, Gregor M, Blin N, Holzmann K: Epigenetic control of the E-cadherin gene (CDHI) by CpG methylation in colectomy samples of patients with ulcerative colitis. Genes Chromosomes Cancer 2002, 35:121-126.

68. Nass SJ, Herman JG, Gabrielson E, Iversen PW, Parl FF, Davidson NE, Graff JR: Aberrant methylation of the estrogen receptor and E-cadherin 50 CpG islands increases with malignant progression in human breast cancer. Cancer Res 2000, 60:4346-4348.

69. Umbricht CB, Evron E, Gabrielson E, Ferguson A, Marks J, Sukumar $S$ : Hypermethylation of 14-3-3 $\sigma$ (stratifin) is an early event in breast cancer. Oncogene 200I, 20:3348-3353.

70. Bhatia K, Siraj AK, Hussain A, Bu R, Gutierrez MI: The tumor suppressor gene 14-3-3 $\sigma$ is commonly methylated in normal and malignant lymphoid cells. Cancer Epidemiol Biomarkers Prev 2003, 12:165-169.

7I. Lombaerts M, Middeldorp JW, Weide E van der, Philippo K, van Wezel T, Smit VT, Cornelisse C], Cleton-Jansen AM: Infiltrating leukocytes confound the detection of E-cadherin promoter methylation in tumors. Biochem Biophys Res Commun 2004, 319:697-704.

72. Cianciulli AM, Leonardo C, Guadagni F, Marzano R, lori F, De Nunzio C, Franco G, Merola R, Laurenti C: Genetic instability in superficial bladder cancer and adjacent mucosa: an interphase cytogenetic study. Hum Pathol 2003, 34:214-221.

73. Trkova M, Babjuk M, Duskova J, Benesova-Minarikova L, Soukup V Mares J, Minarik M, Sedlacek Z: Analysis of genetic events in $17 \mathrm{p} \mid 3$ and $9 \mathrm{p} 21$ regions supports predominant monoclonal origin of multifocal and recurrent bladder cancer. Cancer Lett 2006, 242:68-76.

74. Smith LT, Otterson GA, Plass C: Unraveling the epigenetic code of cancer for therapy. Trends Genet 2007, 23:449-456.

75. Sidransky D: Nucleic acid-based methods for the detection of cancer. Science 1997, 278:1054-1059.

76. Yu J, Zhu T, Wang Z, Ahang H, Qian Z, Xu H, Gao B, Wang W, Gu, Meng J, Wang J, Feng $X, L i$ Y, Yao $X$, Zhu J: A Novel set of DNA methylation markers in urine sedments for sensitive/specific detection of bladder cancer. Clin Cancer Res 2007, 13:7296-7304.

77. Dulaimi E, Uzzo RG, Greenberg RE, Al-Saleem T, Cairns P: Detection of bladder cancer in urine by a tumor suppressor gene hypermethylation panel. Clin Cancer Res 2004, 10:1887-1893.

\section{Pre-publication history}

The pre-publication history for this paper can be accessed here:

\section{http://www.biomedcentral.com/1471-2407/8/238/pre} pub 